\title{
Military doctrine, command philosophy and the generation of fighting power: genesis and theory
}

Article

Accepted Version

Sloan, G. (2012) Military doctrine, command philosophy and the generation of fighting power: genesis and theory. International Affairs, 88 (2). pp. 243-263. ISSN 1468-2346 Available at https://centaur.reading.ac.uk/26463/

It is advisable to refer to the publisher's version if you intend to cite from the work. See Guidance on citing.

Published version at: http://www.chathamhouse.org/publications/ia/archive/view/182474

Publisher: Wiley-Blackwell

All outputs in CentAUR are protected by Intellectual Property Rights law, including copyright law. Copyright and IPR is retained by the creators or other copyright holders. Terms and conditions for use of this material are defined in the End User Agreement.

www.reading.ac.uk/centaur

\section{CentAUR}

Central Archive at the University of Reading 
Reading's research outputs online 


\section{Military Doctrine, Command Philosophy, and the Generation of Fighting Power: Genesis and Theory \\ 'Let us learn to think in the same way about fundamental truths' \\ Darrieus}

It was the British maritime strategist, Sir Julian Corbett who, on the eve of the First World War, described doctrine as:" the soul of warfare" ${ }^{11}$.This conceals as much as it reveals, leaving out any explanation of how doctrine is formulated, disseminated or used, and the relationship between doctrine and command philosophy. It is only through a synthesis of these two factors that fighting power can be generated. Doctrine's ultimate function can be described as a force multiplier in that a fighting organization that applies it consistently will be able to take on a larger force in battle and win. It is often analyzed and evaluated in isolation of command philosophy. How do we define doctrine and what are the major variants of command philosophy? What is the nature of the relationship between doctrine and command philosophy? Is it possible to identify and assess the component parts of doctrine, and to understand how they manifest themselves at the tactical, operational and strategic levels of war?

The important context for answering these questions is the fighting power of a state's armed forces_which is a product of physical factors (eg human resources, equipment):moral factors(eg leadership, management and motivation)and conceptual factors(eg doctrine, force development and the principles of war). Both the physical and the moral component feed into and are dependent on the conceptual component. ${ }^{2}$ It is the sustained functioning of this nexus, when combined with the appropriate command philosophy, that creates a force multiplier effect. This synthesis has the ability to generate fighting power.

The first question is how do we define doctrine? The North Atlantic Treaty Organisation interprets it as " fundamental principles by which military forces guide their actions in support of objectives". ${ }^{3}$ This spartan definition does not help to answer

\footnotetext{
${ }^{1}$ J. Corbett, Staff Histories, taken from Naval and Military Essays, Cambridge: Cambridge University Press, 1914 p24.

${ }^{2}$ This is summarised from the British Defence Doctrine,(JDP 0-01) $3^{\text {rd }}$ Edition ,August 2008 pp 4-1 4-10.

${ }^{3}$ AAP-6 The NATO Glossary of Terms and Definitions.
} 
one important question that needs to be addressed. How do you understand and evaluate doctrine as an object of thought? This can only be achieved by highlighting a number of interrelated perspectives. In one sense doctrine, if it is interpreted literally, means what is taught. The word comes from the Latin term doctrina meaning teaching. This in turn raises the question, who is it taught to? The term had utility in the context of the Roman Catholic Church. It was used to designate the accepted and correct articles of faith taught by the church. Although the term can be said to predate the Catholic Church. Doctrine can also be understood as a set of corporate beliefs or the principles which guide an organization on how it interacts with a wider environment.

The second perspective in understanding doctrine as an object of thought is to conceive it as embodying the vital link between theory and practice. As far as military doctrine is concerned this can be said to have its roots in the early drill manuals such as those promulgated by Maurice of Nassau in the $17^{\text {th }}$ Century. ${ }^{4}$ The modern concept of doctrine attempts to avoid being overly prescriptive the aim being to ensure that a descent into dogma ${ }^{5}$ was avoided. Instead the objective was to develop a conceptual framework that would be the most effective in terms of undertaking military operations. One of the criteria for measuring this effectiveness is the degree to which military doctrine acted as a force multiplier. Doctrine can be conceived as a bridge between thought and action .It interprets ideas about war and how they affect its conduct and its character by combining strategic theories and operational plans into functional guidelines for action. Put another way military doctrine articulates war. ${ }^{6}$ It is important to stress that definitions and the relationship between these elements have not always been clear: "Military writers do not agree on definitions of the terms strategy, military doctrine, and tactics. In simplest terms, however, tactics is the study of how battles will be fought. In my view, once one begins to ask questions about how battles will be fought, one has entered the realm of military

\footnotetext{
${ }^{4}$ Maurice of Nassau (1567-1625) organised the rebellion against Spain into a coherent ,successful revolt .He used drill not just to instil discipline or to keep men physically fit, but also to disseminate tactics. This change affected the conduct of warfare as it required officers to train men in addition to leading them. It also decreased the size of an infantry unit for functional purposes as more specific orders could be given. It also required more initiative and intelligence from the average soldier.

${ }^{5}$ Dogma in this sense is interpreted as an established belief that is unchanging.

${ }^{6}$ This phrase is taken from the title of a doctoral thesis submitted to Reading University in 2009.See FN 9.
} 
doctrine .When one begins to ask which wars will be fought, or if war should be fought one has entered the realm of strategy."7

The final perspective in understanding doctrine as an object of thought is to understand what this bridge consists of. More specifically what processes have to be undertaken for doctrine to have a force multiplying effect? Colin Gray has argued for the need to recognize a compulsory partnership with respect to one of the key dimensions of this bridge: "Strategy and doctrine, doctrine and strategy, are necessary partners. Strategy decides how policy's goals are to be advanced and secured, and it selects the instrumental objectives to achieve these goals .Military doctrine, for its vital part, explains how armed forces of different kinds should fight .Doctrine should be the subordinated party in their necessary partnership, but such is by no means the case. The reason is because the doctrines with which armed forces implement strategy must shape the expectations and the plans of strategists." 8

\section{Perhaps the most important aspect is the winning of institutional} approval: "Military theory is the body of ideas that concern war, especially those that are involved in the organization for training and fighting war. Doctrine is that accepted body of ideas concerning war. The acceptance of ideas can be the result of long-term usage or official sanctioning by the appropriate military authorities in a particular Service branch, nation or specific group. After examination and acceptance by highly experienced professionals that constitute the various review groups and doctrine committees, theory and best practice becomes doctrine". ${ }^{9}$ Apart from institutional approval doctrine needs to provide enablers to succeed in warfare. In evaluating this critical quality of the doctrine bridge, it has to contain one key element namely "a set of beliefs about the nature of war."10

Doctrine at the tactical, operational, and strategic level of war performs different functions which are linked together. At the strategic level doctrine provides direction and understanding. At the operational level doctrine provides understanding and instruction.

\footnotetext{
${ }^{7}$ B. Posen, The Sources of Military Doctrine: France, Britain , and Germany Between the World Wars, Ithaca: Cornell University Press, 1984 p245.

${ }^{8}$ C.S. Gray, The Strategy Bridge ,Oxford :Oxford University Press ,2010 p78.

${ }^{9}$ J.S. Sauboorah, The Articulation of War: An Assessment of British Military Doctrine, PhD thesis University of Reading ,2009 p3.

${ }^{10}$ J.Snyder, The ideology of the offensive : Military Decision Making and the Disasters of 1914.,Ithaca \& London: Cornell University Press 1984,p27.
} 
Finally, at the tactical level doctrine provides instruction and training. Doctrine should also be regarded as a seamless web: it should define how an armed force trains in peace, the weapon systems that it procures, and the way it fights in war. There is also a critical difference between doctrine and a set of orders. While both are authoritative, the former requires judgement in application, and is dependant on the nature of the orders which are received. This gives doctrine its unique character and underlines both its strengths and weaknesses in the trinity of components that contribute to the generation of fighting power. It can become dated very quickly. Therefore there is an onus on senior commanders to ensure that doctrine changes as circumstances, character and the conduct of a particular war dictate. In this sense doctrine is potentially an unstable phenomenon. The danger is to rely on its permanence and so fail to re-assess its relevance and to reacquire doctrine in the light of new circumstances. It is easy for doctrine to become dogma and in due course fail to act as a force multiplier.

The other key quality doctrine needs is an ability to steer transition. It must start at the tactical level and ultimately produce tempo. This quality, or the lack of it, has been well summarized in the context of the recent conflict in Iraq: "We failed to apply our tactical doctrines to operational effect in the pursuit of strategic goals. At the heart of successful tactics is the concept of transition-the ability to switch between operations of war. Get your transitional procedures right and tempo-the ability to outpace your enemy on the battlefield- follows naturally". 11 This ability to steer transition can be said to represent one of the vital prerequisites of tactical doctrine.

Having identified a number of interrelated perspectives that enable doctrine to be understood as an object of thought, it is intended to outline the two major variants of command philosophy. In one sense any command system has a simple aim: to bring about the correct alignment of authority and responsibility among the various levels in a military hierarchy: "Without striking a correct balance between centralization and decentralization, discipline and initiative, authority and individual responsibility, it is impossible for any organization, let alone a military one, operating as it does in an environment where disorder and confusion are endemic-to function or ,indeed exist."

\footnotetext{
${ }^{11}$ R. Fry, Expeditionary Operations in the Modern Era, RUSI Journal, December 2005 vol. 150 , no.6 p62.

12 M.van Creveld ,Fighting Power, London:Arms and Armour Press 1983 p35.
} 
The first variant can be described as centralised control. The German word Befehlstaktik (orders based tactics) refers to this concept. This restrictive approach informs the command chain why, when, and critically how operations will be carried out. The second variant is often referred to as Auftragstaktik (mission based tactics).This approach informs the command chain why and when operations will be carried out, but, critically delegates the how to the initiative of officers in the command structure. ${ }^{13}$ It is often referred to as mission command. Giving practical expression to this is not straightforward: "Mission Command is a complex ,elusive and multi-factorial phenomenon not easily quantified or measured". 14

In terms of land warfare the latter approach has been closely identified with the Prussian military tradition. This second variant has its origins in the social structures and ethos of Prussia: "This was a tradition that harkened back to the old Prussian social system, particularly the distinct social contract between the king and the Junker nobility. In return for the Junker's fealty and service, the king allowed them near total control over the peasants in their domains. This arrangement was extended to the general's relationship with his troops who could deploy them in any operational manner that he saw fit." $" 15$ The crucial relationship between doctrine and command philosophy had developed further by the nineteenth century. German military reformers and thinkers such as Field Marshal Helmuth von Moltke, the Elder stressed that "adherence to a battle plan must not be allowed to crush the initiative of individual commanders and that the Feldherr (Theatre Commander) must have the courage and wit to change his dispositions as the situation required."16. This relationship evolved, and in the post- First World War era, underwent what could be described as a renaissance. Prior to and during the First World War the German Army operated on a command philosophy known as Weisungsfuhrung (leadership by directive) ${ }^{17}$. This devolved responsibility down to army

\footnotetext{
${ }^{13}$ For a detailed discussion of the development of the second variant see :B.Condell and D.T.Zabecki,On the German Art of War Truppenfuhrung, London: Lynne Rienner,2001p3-6.

${ }^{14}$ E.Shamir, The Long and Winding Road :The US Army Managerial Approach to Command and the Adoption of Mission Command(Auftragstaktik), Journal of Strategic Studies, Vol 33,No 5 ,October 2010 p668.

${ }^{15}$ Weichong Ong, Blitzkrieg: Revolution or Evolution? RUSI Journal December 2007 vol.152 no.6 p88.

${ }^{16}$ D.Abenheim, Reforming the Iron Cross: The Search for Tradition in the West German Armed Forces, New Jersey: Princeton University Press1988,p18.

${ }^{17}$ See R.T.Foley, German Strategy and the Path to Verdun.Erich von Falkenhayn and the Development of Attrition 1870-1916, Oxford: Oxford University Press
} 
or corps commanders and gave them broad discretionary power in the execution of their missions. This approach facilitated the development of fluid, nonlinear infiltration tactics supported by neutralizing artillery fire that the Germans used to great tactical advantage during Operation Michael in 1918.

It was the first head of the inter-war German Army, General Hans von Seeckt who set in motion further developments that were to have a radical impact on both German doctrine and mission command. This could be described as a tripartite approach. First from his own operational experience, on the Eastern front, during the First World War he had witnessed how better trained, better led and better equipped forces could decisively defeat much larger enemy forces. In the aftermath of the war he set up fifty seven committees and sub-committees staffed by 400 officers who would write assessments of the effectiveness of German tactics, regulations, equipment, and doctrine. The aim was to put the recent experience of war into some coherent context. These officers were given clear instructions as to what they were expected to achieve: "The officers named to committees were to write short, concise studies on the newly gained experiences of the war and consider the following points :a). What new situations arose in the war that had not been considered before? b).How effective were our pre-war views in dealing with the above situations? c). What new guidelines have been developed from the use of weaponry in the war? d). Which new problems put forward by the war have not yet found a solution?"18.

The second aspect was the development one of the conceptual components of fighting power: force development. This perspective was both fresh and innovative: "His vision of a Neuzeitliches Heer (modern army) was of special importance to him and became the core of his innovative thinking, even if the restrictions of the Versailles treaty made sure that it remained only a vision. This army would be characterized by a small number of soldiers, who would be well trained and equipped. This would enable the army to conduct a highly mobile war, which Seeckt saw as the key to success in future conflicts."

\footnotetext{
${ }^{18}$ J.S.Corum, The Roots of Blitzkrieg: Hans von Seeckt and the German Military Reform, Kansas: University of Kansas, 1992 p37.

${ }^{19}$ M.Strohn, Hans von Seeckt and His Vision of a 'Modern Army',War in History Vol12 No 32005 p320.
} 
The third element was based on a vision of a need for further doctrinal development. This process was taking place at a time when the German General Staff had been abolished under the Treaty of Versailles, and the Truppenamt (Troop Office ) had been developed as a substitute: "Under Seeckt's guidance, the German army developed the theory and doctrine for a quick war of manoeuvre which would lead to an early decision and fast annihilation of the enemy force. This idea offered some chance for straightforward victory -once the army was expanded and modern equipment acquired"20

A comparative analysis of the British and German approaches is instructive. "Whereas the Germans assigned experienced officers to analyze tactics-the lowest ranking army officers assigned to tactical doctrine studies in 1919-1920 were experienced captains who had been admitted to full membership in the General Staff corps-the British War Office in 1920 assigned the task of rewriting the infantry tactical manual to Liddell Hart, a twenty-four-year old lieutenant of limited experience." ${ }^{21}$ Between 1921 and 1923 the Reichswehr published a new tactical doctrine universally known as a "Das FuG"22. This publication was revolutionary in a number of ways: first it fused together doctrine and a variant of command philosophy while also absorbing many of the tactical developments of the First World War; secondly, prior to 1914 each arm of the German Army had its own publication governing command philosophy and tactics. Not surprisingly this had caused confusion. Das FuG brought together all these disparate approaches into a single publication which remained in use without modification until the early 1930 s.

Finally, the cardinal factor embedded in Das FuG was the extension downwards, in the command structure, of discretionary power in the execution of a mission. This principle was devolved to both squad leaders, and even to individual soldiers. Writing in 1925 in his Observations of the Chief of the Army Command, General Hans von Seeckt noted: "The principle thing now is to increase the responsibilities of the individual man,

\footnotetext{
${ }^{20}$ Ibid p335.

21 .J.S.Corum, The Roots of Blitzkreig : Hans von Seeckt and German Military Reform, Kansas :Kansas University Press ,1992p39. This assertion, which is taken from Liddell Hart's book, "Memoirs" needs to be set against the facts of sustained attempts by the General Staff of the British Army to formulate and update their doctrine in the light of their experiences in the First World War as represented by the Field Service Regulations Part 2(Operations) in the 1920s and 1930s.

${ }^{22}$ Its full title was H.Dv.487,Fuhrung und Gefecht der verbundenen Waffen(Command and Combat of Combined Arms)
} 
particularly his independence of action, and thereby to increase the efficiency of the entire army.....The limitations imposed by exterior circumstances causes us to give the mind more freedom of activity, with the profitable result of increasing the ability of the individual." ${ }^{, 23}$.

This radical idea was subsumed under the existing command philosophy of Auftragstaktik, and was to become incorporated in the seminal German doctrine manual of the 1930s- Die Truppenfuhrung. This view of the future of war was not the only one that was articulated in the German Army of this period : "Running parallel to this was a doctrine of delaying defence that had been formulated by General Beck in the early 1920s, and had become firmly established. It has been suggested that it was not without its dangers. While it enabled the defenders to withstand a higher attack-to-defence ratio, the doctrine was clumsy and dangerous in the hands of a non-expert". 24 Die Truppenfuhrung, was published in two parts the first in 1933 and the second in 1934. It fused together doctrine and command philosophy in a way that was then unique to land warfare. It has been described as :'The finest exposition of the nature of war at the operational level ever written ${ }^{25}$." This publication also built upon the reforms initiated by Von Seeckt. He wanted to build a more cohesive force that was built on trust, mutual respect and comradeship irrespective of social background or one's position in a military rank structure. This change of culture enabled mission- type orders to have a dynamic impact at the tactical level which was unique at the time.: "For Auftragstaktik to work, a subordinate leader or even a common soldier given a mission must fully understand his commander's intent-and in most cases, the intent of the next higher commander. This of course implies that the subordinate leader must understand "why". If he doesn't understand, he has the obligation to ask. Conversely, the superior leader issuing the orders has the obligation to explain" 26 .

This cultural revolution in military affairs is also reflected in the Introductory section of Die Truppenfuhrung. This part of the manual contained fifteen paragraphs

\footnotetext{
${ }^{23}$ Taken from R. Citino, Path to Blitzkrieg, Boulder: Lynne Rienner 1999,p 57.

${ }^{24}$ R.O' Neill, Doctrine and Training in the German Army, taken from The Theory and Practice of War, New York: F.A.Praeger 1966,p153

${ }^{25}$ W. Murray, Thinking About Innovation, Naval War College Review ,Spring 2001 Vol 40,(check)No2.p124.

${ }^{26}$ On the German Art of War Truppenfuhrung, edited by B.Condell and D.T.Zabecki, Boulder: Lynne Rienner,2001 p4.
} 
which created a synthesis between doctrine and command philosophy which was and is unique. The tenth paragraph for example underlines clearly the extent to which a profound cultural change had been brought about in terms of the relations between officers and enlisted men. "The decisive factor, despite technology and weaponry, is the value of the individual soldier. The wider his experience in combat the greater his importance. The emptiness of the battlefield (die Leere des Gefechtfeld) requires soldiers who can think and act independently, who can make decisive, and daring use of every situation, and who understand that victory depends on each individual". ${ }^{27}$ The introduction also sets out very clearly another cultural innovation. Paragraph eight insists that both officers and enlisted men have a responsibility for leadership: "The example and personal bearing of officers and other soldiers who are responsible for leadership has a decisive effect on the troops. The officer, who in the face of the enemy displays coolness, decisiveness, and courage, carries his troops with him.......Mutual trust is the surest foundation for discipline in times of need and danger". ${ }^{28}$

It is important to stress that the formulation of an appropriate doctrine and use of a pertinent command philosophy are only part of the challenge that military organizations face .Perhaps the greater challenge is the dissemination of doctrine. This is best achieved through training; it is this activity that validates doctrine. It was the approach followed by the German army: "At the heart of German training was the inculcating of a progressive, universally taught doctrine: a set of basic assumptions ,beliefs and operating instructions that all German troops irrespective of service, learned and were expected to follow. Adherence to this modern, uniform and realistic doctrine, enshrined in the 1936 Truppenfuhrung (Troop Leadership Manual), was one of the great strengths of the German Army". ${ }^{29}$

Of the two variants of command philosophy that have been outlined, Auftragstaktik fused with a manoeuvre doctrine gave the German Army the potential to generate fighting power. It is important to understand the nature of the challenge that these two command philosophies were designed to meet. They both represented an

\footnotetext{
${ }^{27}$ Ibid p18.

${ }^{28}$ Ibid p18.

${ }^{29}$ S. Hart ,R. Hart, M. Hugher, The German Soldier in World War Two ,Staplehurst: Amber Books ,2000,p8-9.
} 
attempt to do the same thing: to exercise command and control (leadership and management) in the context of war: "Modern war is distinguished above all by its speed and the need for close co-operation between many kinds of specialized troops. This means that other things being equal a command system that allows for initiative on the lowest level and for intelligent co-operation between subordinate commanders ,is likely to be superior to one that does not", 30

It is pertinent at this point to establish exactly what Corbett meant by his aphorism that doctrine is the 'soul of warfare'. It provides us with a way of understanding the relationship between two sets of phenomena: the nature of war, its changing character and conduct and doctrine. By its nature war is fought in an environment of uncertainty, fear, danger, and ambiguity: "The resort to war is also a choice for unpredictably which is not simply the uncertain nature of battle, but the very nature of war" ${ }^{\prime 31}$ There is also the problem of commanders having to rely on information that is only partially accurate, and the risk that some of the information that they will use will be a product of deception by the enemy. It is this changing context within which doctrine has to succeed or fail. Coupled to this is the challenge of understanding the kind of conflict an armed force is going to be involved in. Assessing that correctly is critical, as it will affect how one side, at least, conducts its operations. Clausewitz recognized the importance of what is an intellectual task: "The first, the supreme, the most far reaching act of judgement that the statesman and the commander have to make is to establish the kind of war on which they are embarking, neither mistaking it for nor trying to turn it into something that is alien to its nature. This is the first of all strategic questions and the most comprehensive." 32 .It is in the process of answering this premier question that the departure point for the formulation of doctrine can be discerned. It is at this juncture we can understand the pivotal importance of Corbett's aphorism about doctrine.

Having established the relationship between the nature of war, and the importance of assessing correctly its character, and formulating, disseminating and applying an appropriate doctrine ,it is important to ask two important questions about doctrine itself.

\footnotetext{
${ }^{30}$ M.van Creveld ,Fighting Power,London :Arms and Armour press ,1983 p35.

${ }^{31}$ J.Black, What is War? Some Reflections on a Contested Concept, RUSI Journal December 2007 vol 152 no6 $\mathrm{p} 45$.

${ }^{32}$ Carl von Clausewitz, On War, ed and trans, Michael Howard and Peter Paret Princeton NJ:Princeton University Press, 1979,p88-89.
} 
Firstly, what are the component elements of doctrine? Secondly, how do these components affect the way that doctrine is formulated, disseminated and implemented at the three levels of war? In 1997 Professor Gooch identified six diverse components that produce doctrine. They were set out as follows:

- The nature of weapons technology

- The influence of formative experiences

- Organisational and institutional interests

- Ideology

- National culture

- The political and strategic situation 33

It can be suggested that there is a lacunae in this component based approach to doctrinal theory. Gooch does not evaluate critically how these components manifest themselves at the three different levels of war. The cumulative insights derived from exploring this aspect will further facilitate an understanding of how doctrine has enabled the generation of fighting power.

Before investigating these components it is important to state that other writers have developed alternative interpretations of doctrine. Barry Posen views doctrine as having three dimensions :offensive ,defensive, and deterrence. In addition, there are the categories of innovative or stagnant doctrine, and integration with national policy or the lack thereof. ${ }^{34}$ This view of doctrine has been influential on other writers in the field. Elizabeth Kier states in a footnote: "I have used Barry Posen's definitions of offensive and defensive military doctrines". ${ }^{35}$ Posen's approach can be characterized as one where the varieties of doctrine fused with a broad definition are sufficient to critically evaluate the sources of British, French and German in the inter-war period.

By contrast Gooch's doctrinal components enables the effectiveness of a specific doctrine to be investigated with greater precision. This is important for two reasons. First doctrine

\footnotetext{
${ }^{33}$ J. Gooch, Military Doctrine and Military History, taken from The Origins of Contemporary Doctrine, The Occasional, Strategic and Combat Studies Institute No30,September 1997,p6

${ }^{34}$ B. Posen, The Sources of Military Doctrine: France, Britain and Germany Between the World Wars ,Ithaca :Cornell University Press ,1984 p14.

${ }^{35}$ E. Kier ,Imagining War: French and Military Doctrine Between the Wars ,Princeton :Princeton University Press 1997,FN ,p173.
} 
represents the link between thought and action. Secondly, as previously stated, ${ }^{36}$ there is an onus on senior commanders to ensure that doctrine changes as the circumstances, character and the conduct of a particular war dictates. The circumstances in which doctrine will be formulated will be unique. This analytical approach helps to understand how the components of a specific doctrine had utility. It is also important to stress that a doctrine has an impact on more than just the enemy. There is the requirement for doctrine to be alliance friendly: "Doctrine to be of value must guide thought and appropriate action or it will not act as the binding agent of all the separate operational practices...doctrine must be sufficiently encompassing to accommodate the allies.",37

Gooch's first component, weapons technology, is by far the most important. It is part of the :" compound alignment of technology, doctrine and command philosophy that can generate fighting power" ${ }^{, 38}$.There is no doubt that certain technological developments in metallurgy, gunpowder, and the invention of weapons such as the crossbow gave their possessors tactics an ability to steer transition that enabled them to have operational effect and achieve strategic objectives. Yet technology was and is only an enabler. What really mattered was the doctrine within which this technology was employed. This process of conceptualization was not automatic. It often took a number of years for a particular doctrine to emerge, and was also dependant on another of the components that will be examined later such as- organizational and institutional interests. The development of combined arms warfare in Germany in the interwar period was a good example of this. ${ }^{39}$ The analysis of the use of tanks during the First World War was the first step. Heinz Guderian came to the conclusion that without mechanical assistance even the German infantry of 1918 would pay a heavy cost to achieve a breakthrough. Perhaps more importantly events had shown that the German Army had been unable to develop that transitory quality in their tactical doctrine during Operation Michael, and ultimately failed to have an operational effect and facilitate the achievement of strategic objectives.

\footnotetext{
${ }^{36}$ See p4.

${ }^{37}$ Communication from General Sir Rupert Smith to the author ,dated $11^{\text {th }}$ March 2008.

${ }^{38}$ Communication from Lt Gen Sir Rob Fry RM to the author, dated $2^{\text {nd }}$ October 2009.

${ }^{39}$ See H. Guderian, Achtung Panzer, Arms and Armour Press: London 1992
} 
Technology can act like a double edged sword. It can initially affect a particular level of war, and weapons technology can increase the importance of a level of war, and ultimately require a riposte from the opposing side: "The first great wave of technologies privileged above all firepower, strategic mobility, and strategic communications. The result in the First World War was tactical and operational immobility and the horror of immense losses for virtually no visible gain." 40 In essence doctrine can bequeath force generating advantages at one level and present profound challenges at other levels of war. The manifestation of this kind of doctrinal challenge can be illustrated by the British Army in the First World War. It was not until 1918 that the British Army produced an effective operational level doctrine that facilitated the achievement of strategic objectives. This was British Expeditionary Force's (BEF) Division in Attack-S135.This was the doctrine that was used during the successful 'Hundred Days' campaign from August to November $1918 .^{41}$

The second component of doctrine is the influence of formative experiences. Military organizations are often accused of fighting the last war. The challenge to any armed force is the need to distil the continuities from the discontinuities. The logic would then be to build a new doctrine of the foundation stone on the former. This would then inform the tactical, operational and the strategic levels of doctrine. While the past cannot be a sure signpost to the future Gooch suggests that: "It can, nonetheless, be of some assistance to those whose present-day task is to write the doctrine of tomorrow" ${ }^{\prime 4}$.It can provide a comprehension as to whether the ability to steer transition was in evidence at the tactical level. The other problem is that peace presents unique problems in terms of developing new doctrines based on the experiences of the past: "The basic problem is that military organizations can rarely replicate in times of peace the actual conditions of war. It becomes increasingly easy as the complexities, ambiguities, and frictions of combat

\footnotetext{
${ }^{40}$ M. Knox , Conclusion: Continuity and Revolution in the Making of Strategy, From W. Murray ,M Knox and A. Bernstein, The Making of Strategy ,Rulers States and Wars, Cambridge :Cambridge University Press., 1994 P639.

${ }^{41}$ See The Division in the Attack-1918 SS135 40/WO/7036 The Occasional -Number 53, Strategic and Combat Studies Institute 2008.

${ }^{42}$ J.Gooch ,'Introduction; Military Doctrine and Military History, Strategic and Combat Studies Institute Occasional Paper 45:The Origins of Contemporary Doctrine 1997 p6.
} 
recede into the past, for militaries to develop concepts, doctrines, and practices that meet the standards of peacetime efficiency rather than those of wartime effectiveness" ${ }^{\text {" }}$.So the period during which a fighting organization has the opportunity to place the experiences of a recent conflict into a broader light is laced with distracting challenges. The most prominent is the temptation to set aside painful experiences which then have to be relearnt at a later date.

The experience of the United States Army is instructive in this respect. When it left Vietnam in 1973 it faced two broad challenges. It found itself having to align the organization with one of the other components of doctrine - the political and strategic situation. The Nixon Doctrine of 1969 placed a re-emphasis on the defence of Western Europe over other parts of the world. Secondly, American statesmen and commanders had failed to successfully answer the premier Clausewitzian question with respect to the nature of the war they were fighting. This failure in turn had consequences: "The politico-military leadership had lost any moral or professional credibility it may have enjoyed. The war had not supplied this army with institutional heroes around whom the faithful could rally. Under the circumstances, neither vision or visionary seemed possible. ${ }^{, 44}$ Worse than this, the inappropriate configuration of the US Army had been recognized by only a handful of officers : "I felt that we sent an army to Vietnam that was not prepared to fight the war. We sent an army that was top heavy in administrators and logisticians and bloody thin on fighters, not trained for the war. I felt that we didn't understand the nature of the war in the military" 45 The defeat that it suffered in Vietnam also brought with it multifaceted problems. It was :"an army that was suffering from the after effects of the war in Vietnam. In addition to both professional and morale crises at all levels of the Army, the trauma of Vietnam created a crisis of confidence between the military and the public, the Congress, and the executive branch" ${ }^{\prime 4}$.

\footnotetext{
${ }^{43}$ W. Murray, Thinking About Innovation, Naval War College Review Spring 2001 VOL ? No2 p122.

${ }^{44}$ R.J. Spiller, In the Shadow of the Dragon, RUSI Journal, December 1997,Vol142, No 6 p43.

${ }^{45}$ Col D. Hackworth, About Face, London: Guild Publishing 1990 p781.

${ }^{46}$ S. Bronfeld ,Fighting Outnumbered: The impact of the Yom Kippur War on the U.S. Army, Journal of Military History Vol 71,No2,April 2007 p469.
} 
Despite these problems the U.S. Army between 1973 and 1976 successfully re-invented itself in many respects. ${ }^{47}$ Perhaps most instructive in terms of the formulation of doctrine there can be discerned the heavy use of formative experiences, although interestingly not its most recent ones nor exclusively its own. This doctrinal genesis would not have been possible without the establishment of the Training and Doctrine Command (TRADOC) on the $1^{\text {st }}$ July 1973.The first commanding officer was General William De Puy. Despite the fact that he had been was one the senior commanders in Vietnam, the personal formative experience that was critical to the process of doctrinal formulation was not this war: "The defining experience for DePuy was his service in the European theater in World War 2 .As an officer in the $90^{\text {th }}$ Infantry Division, he was struck by the weaknesses of the U.S. Army: notably, unrealistic training that did not prepare the soldiers properly for the battlefield and the appointment of unqualified officers....De Puy's other revelation during World War II concerned the tactical excellence of the German Army.",48

The second formative experience was a war that the United States Army did not participate in, the Yom Kippur War of October 1973. Its timing was fortuitous in that it appeared to offer a contemporary example of the kind of conflict that could occur along what was then the inner German border. Direct evidence of the influence of this war on the process of doctrinal formulation can be found in a statement made by Lt General Orwin C.Talbott, De Puy's deputy who visited Israel in February 1974. After meeting forty-five Israeli Army officers he declared: "Much, perhaps most important, of what we learnt (about the tactical aspects) is not new, but needs a re-emphasis and confirms most of our tactics and doctrine." 49 .

The result was the publication in 1976 of FM 100-5. This represented a tactical doctrine called Active Defense that called upon U.S. commanders to move their units and rapidly change the force ratio at key points. It had moved the existing doctrine beyond static defense or a mobile defense relying on territorial depth. In short it was the force

\footnotetext{
${ }^{47}$ A good example of this was the abandonment of the draft and the inception of an all volunteer force.

${ }^{48}$ S.Bronfeld ,Fighting Outnumbered: The Impact of the Yom Kippur War on the U.S.Army, Journal of Military History Vol 71,No 2 April 2007p471.

${ }^{49}$ Quoted in Ibid p472.
} 
multiplier that would enable the U.S. Army to win the first battle of the next war while fighting superior numbers of Warsaw pact troops. In 1982 a new version of FM 100-5 included an operational level doctrine that had been developed between 1977 and 1981.The operational doctrine was called the Extended Battle, and was later called the Air-Land Battle .It is often credited with being the conceptual basis for the planning of Operation Desert Storm in 1991. It has also been argued that the first component of doctrine - weapons technology was also important in this process: "The new systems based on emerging technologies, enabled an operational doctrine that synchronized the engagement of the follow-on echelons with defense against the first echelon. There was also a need to put doctrinal and organizational muscle on the technological skeleton" Finally, it is important to note that this doctrine received endorsement from the Bundeswehr, the main continental European army that the United States Army would fight with in the event of hostilities with the Warsaw Pact. This component of doctrine it has been shown was dependent on two others: weapons technology and the political and strategic situation. Furthermore, it manifested itself first at the tactical before being extended to the operational level.

The third component is organizational and institutional interests. Initially it would appear that this dimension is ephemeral to doctrine in a way that is the converse of weapons technology. Doctrine, in a normative sense, is a result of the successful response to the premier question. From it an armed force can conceive a form of war that is considered best suited to a particular conflict. Once this process has been successfully completed, there is a requirement for an organizational and institutional structure to sustain it. An insight to this relationship was given in an anonymous article that was published in 1911 . Corbett was probably the author. This article accused the British General Staff of failing to formulate a doctrine that could be adequately supported by the organization.: "The General Staff selected for the Army a 'method of action' that has failed to give it a 'doctrine of war', not because it has formed no particular 'conception of war', but because it does not consider the organization and administration of the army as yet quite

\footnotetext{
${ }^{50} \operatorname{Ibid}$ p494.
} 
adequate to the tasks which would be imposed on it by the form of war that it considers the best". 51

Another aspect of this component could be described as internal culture. This can play an important role in military innovation: "The services that innovated with considerable success in the interwar period possessed internal cultures that encouraged debate, study, and honest experimentation in their preparations for war. Professional military education was clearly a part of the process ;so was serious study and writing.....The German army particularly encouraged its officers to engage in serious debate"

Internal culture can also have a negative impact on the effectiveness of doctrine. The British Army of the inter-war period provides an instructive example of this. Despite being accused of failing to study the lessons of the First World War ${ }^{53}$ there is a wealth of evidence to suggest a contrary conclusion :'The General Staff promulgated its initial thoughts on the lessons of the Great War as early as 1920,when it published the first postwar edition of the Field Service Regulations. Two amended editions followed in the 1920 s, the second in 1924 and the third in 1929 "54 .Furthermore, it can be suggested that by the end of this decade the General staff had developed a tactical combined arms doctrine based on combat experience of the First World War, and post war developments. Surprise coupled with the deployment of technology generated firepower and the minimal use of manpower was seen as the pathway to victory in future wars.

Yet this doctrine failed to find expression owing to two factors. First there was a lack of new weapons systems that would enable this new doctrine to be validated by training. However, this was not a problem that was unique to the British Army. The Reichswehr lacked modern equipment in the same way, yet they did not have the same problem of validating their doctrine through training. Why was this so? The answer lies in the second

\footnotetext{
${ }^{51}$ Edinburgh Review, Vol133,April 1911 p346.

${ }^{52}$ W. Murray, Thinking About Innovation, Naval War College Review ,Spring 2000 ,Vol 54 No2 p128. ${ }^{53}$ See Ibid p124.

${ }^{54}$ D French, Big Wars and Small Wars between the wars 1919-1939. From H. Strachan, Big Wars and Small Wars: The British Army and the Lessons of War in the Twentieth Century, London: Routledge, 2006 p39.
} 
factor. Any attempt by the General Staff to impose a common understanding of the combined arms doctrine was undermined by a weak management and inspection system: "The interpretation of doctrine was apt to change with every posting of a senior officer". 55 Added to this the tactical training of junior officers was devolved to unit commanders and their second-in-commands. The consequence was that quality of the doctrinal understanding and training acquired a huge disparity between individual units. This problem was not systematically addressed until July 1939. This was too late to make any difference to the operational performance of the British Expeditionary Force in 1940.

The third factor is something that affects all organizations whose role is to prepare for and fight wars. Their efforts to formulate, disseminate, and implement doctrine are frequently challenged by two of the other components of doctrine: changing geostrategic circumstances and technological innovation. This has given rise to a remarkably pessimistic assessment by Sir Michael Howard as to whether militaries can actually be counted on to become effective learning institutions: "I am tempted to declare dogmatically that whatever doctrine the Armed Forces are working on now, they have got it wrong. I am also tempted to declare that it does not matter that they have got it wrong .What does matter is their capacity to get it right quickly when the moment arrives". ${ }^{56}$ The capacity to be a learning institution can also affected by another component of doctrinenational culture. Sir Michael Howard illustrates this with trenchant criticism of the culture that has been dominant in British Isles : "Still do not let me give too much encouragement to that English vice of laziness masquerading as pragmatism. The appalling dictum of the lazy man, that the British Army loses all battles except the last, glosses over a vast quantity of misery and bloodshed, not least at the expense of Britain's allies". 57 The influence of organizational and institutional factors is something that can manifest itself at all three levels of war. In particular it can impede the development of a tactical doctrine and the appropriate command philosophy which is critical to the

\footnotetext{
${ }^{55}$ D. French, Officer Education and Training in the British Regular Army, 1919-39, From G.C. Kennedy \& K. Neilson, Military Education Past Present and Future, Abington :Routledge 2002 p1 15

${ }_{56}$ M. Howard, Military Science in an Age of Peace ,RUSI ,March 1974, Vol 119, No1,p7.

${ }^{57}$ Ibid p7.
} 
transitory quality that tactics need if they are to have operational effect and achieve strategic objectives.

Ideology from the perspective of armed forces in Western liberal democracies, initially appears to be an anomaly as far as doctrine is concerned. Yet it has been a critical element of doctrine since the end of the eighteenth century: "It is ideology, the secular variant of religion that has exerted the most potent influence over strategic policy during the past two centuries. The French Revolution and the nearly quarter century of war that ensued set the tone for the twentieth century. Secular religions particularly plagued the first half of our century and came close to breaking the back of Western civilization during World War II " ${ }^{" 58}$ In terms of how it has manifested itself ideology has had the greatest impact at the strategic level and it will be shown that it can have an impact at the operational and tactical level. This component can be likened to what T.S. Elliot described in one of his poems as a 'wilderness of mirrors'. It offered the solace of a distorted reality. In the twentieth century one of the best, although not the only, illustration of this was Nazi Germany. This was a regime that developed an ideology of International Relations that stressed the notion of a Social Darwinist struggle for survival. In terms of strategic objectives there was an emphasis of a war for Lebensraum (living space) in the East. War and military preparations was a factor that suffused both German society and its foreign policy. It had done so, with a less lurid vocabulary, even during the reign of Wilhelm 11, and this complemented a military tradition that went back to the Second Reich. ${ }^{59}$

The success of the Wehrmacht in Poland and the Norway and then France and the Low countries was based on the successful use of a combined arms warfare doctrine which facilitated the innovative and very efficient employment of limited resources. The invasion of Russia with the launch of Operation Barbarossa in June 221941 marked a discontinuity that was to have important implications for the ideological component. First

\footnotetext{
${ }^{58}$ W. Murray \& M. Grimsley, On Strategy, From The Making of Strategy, Rulers, States, and War, Cambridge: Cambridge University Press 1994. p15

${ }^{59}$ See E.R. Wolf ,Envisioning Power, Ideologies of Dominance and Crisis, Los Angeles: University of California Press, 1998 p220.
} 
the gross underestimation of the logistical problems of invading Russia meant that the doctrine of combined arms warfare could not be adequately supported beyond December 1941, when the German offensive was halted in the suburbs of Moscow. Secondly, the attack on Russia had an ideological dimension to it that had been absent from previous offensives in the West. From the beginning the war in Russia was characterized as a Weltanchauungskrieg-a war of ideology. This aspect of the conflict could be sustained relatively easily in the German Army which was an organization already adept at using radio, film, written propaganda to convey important messages to its soldiers. ${ }^{60}$

As the gap in resources and technology between the Red Army and the Wehrmacht widened in 1942-1943, the transitory power of the latter's tactical doctrine was increasingly challenged. A consequence of this there was an increasing recourse by the leadership of the Third Reich to inserting ideology into the command structure. The aim was to explain the political situation and harden morale of German soldiers. For example: "On $22^{\text {nd }}$ December 1943 Hitler issued an order establishing 'NS-Fuehrungsstab' in the OKW which made for the creation of 'National Socialist Leadership Officers' (NSFO) in all military staffs down to divisional level. Thus ended a gradual process, begun almost ten years earlier, of an ideological and institutional penetration of the army by the Nazi party" ${ }^{61}$ Some divisions of the German Army had company commanders conduct biweekly ideology sessions with their men. This increased emphasis on propaganda was combined with a belief in the Fuhrer by German soldiers ${ }^{62}$.This had the effect of stiffening their morale, even in defeat. Yet ultimately it did not prove an antidote to the greatest challenge that the German Army faced from 1942 onto onwards which was that of the process of de-modernisation. In a perverse way the increased emphasis on ideology between 1942 and 1943 can be interpreted as a substitute for combined arms warfare doctrine of war that could no longer generate the fighting power that it once had been capable of. Ideology, which seemed a force multiplier when things went well, gave the

\footnotetext{
${ }^{60}$ See O. Bartov, The Eastern Front ,1941-1945,German Troops and the Barbarisation of Warfare, London: Macmillian Press 1985 P69-76.

${ }^{61}$ Ibid p75.

${ }^{62}$ Ibibp104
} 
German High Command a very poor alternative to attaining operational effect and reaching strategic objectives.

If the armed forces of any country are a product of the society that produced them national culture is a component of doctrine. Yet this proposition presents a number of problems. First the concept of culture is both contested and unbounded. Culture means anthropology, historical sociology, international security, organization theory, psychology, sociology and social theory. Any concept and definition of culture is problematic. The anthropologist Clifford Geertz in the Weber tradition states that: "Man is an animal suspended in webs of significance he himself has spun". ${ }^{63}$ In short, people live in a symbolic world that they themselves have socially constructed or inherited and action is taken in this symbolic environment. Cultural explanation according to this approach is based on signs, symbols and their interpretation. With respect to national culture and doctrine this raises the question as to whether the former should be seen as context as Colin Gray has suggested, ${ }^{64}$ Alistair Finlan has suggested another relationship between a specific fighting organization and national culture: "They share much in common, from an explicit focus on identity and an awareness of the power of social construction and the influence of ideas, norms, values as well as identity in shaping preferences .An important historical linkage between the two areas has been in relation to the significance of doctrine in shaping the preferences of military establishments". ${ }^{65}$ Inevitably scholars who have written about this topic have taken different perspectives on its influence on doctrine, fighting forces and the choices of strategies: Snyder stressed the pressures that are generated within a particular military organization ${ }^{66}$. Posen laid a far greater emphasis on the political elite of a particular country and the balance of power

\footnotetext{
${ }^{63}$ Clifford Geertz, The Interpretation of Cultures ,New York: Basic Books ,1973 ,p.5.

${ }^{64}$ C. Gray, Modern Strategy, Oxford: Oxford University Press 1999,p????

${ }^{65}$ A. Finlan, A Comparative Study of US/UK Military Culture and the Global War on Terror, unpublished thesis RCUK Academic Fellowship, Aberystwyth University 2010,p6.

${ }^{66}$ J.Snyder, The Ideology of the offensive:Military Decision Making and the Disasters of

1914,Ithaca:Cornell University Press,1989
} 
within the international system. ${ }^{67}$ Finally, Rosen invoked external factors and technology. ${ }^{68}$

What is instructive about Finlan's ideas is that he then qualifies the proposition about doctrine shaping preferences: "The causal chain between doctrine as an independent variable and strategy as a dependent variable is not at all assured, even more so, in times of conflict" $" 69$.

If the weapons technology component of doctrine can generate fighting power only when it is employed within a certain conceptual framework, then a similar claim can be made for national culture. It provides a crucial context that can have both negative and positive implications for the formulation, dissemination implementation of doctrine. Not only is an interdisciplinary approach unavoidable in explaining this approach, but it has also been argued that these diverse factors are in turn refracted through the prism of constitutional arrangements: "The measures which communities adopt for their defense are intimately connected with their internal political structure, and in consequence with their traditions and their ideas". 70

The negative effects of this component are illustrated by returning to the British Army in the inter-war period. The Field Service Regulations of the 1920s and 1930s articulated general principles. They did not prescribe how those principles should be applied. Instead this responsibility was devolved to senior officers on the assumption that implementation would require a combination of judgement and experience. Part of the reason for this were the strategic realities of the British Empire: pulled between preparing to fight a European war and colonial garrisoning duties. However, David French has claimed that national culture was also an important driver: "This indulgent

\footnotetext{
${ }^{67}$ B. R. Posen, The Sources of Military Doctrine: France ,Britain and Germany Between the World Wars, Princeton :Princeton University Press

${ }^{68}$ Stephen Peter Rosen Winning the Next War: Innovation and the Modern Military, Ithaca: Cornell University Press 1994.

${ }^{69}$ A.Finlan, A Comparative Study of US/UK Military Culture and the Global War on Terror ,unpublished thesis RCUK Academic Fellowship, Aberyswyth University 2010,p7.

${ }^{70}$ M.Howard, Introduction The Armed Forces as a Political Problem, Ed M. Howard, Soldiers and Governments, London: Eyre and Spottiswoode, London 1957,p23.
} 
approach to the interpretation of doctrine was also the creation of a particular notion of what it meant to be 'British' that had developed since the eighteenth century. It was widely assumed that one of the factors that set the British apart from the Germans or French, and made them superior was the fact that their actions were determined by 'character' not abstract reason and prescriptive rules... a readiness to muddle through was a trait that was supposed to distinguish the British from their continental neighbours" This idea of character in this sense was also linked to a unique conception of liberty; "Our liberty is neither Greek nor Roman ,but essentially English. It has a character of its own" ${ }^{, 72}$.The debate between this British emphasis on character, and the subsequent erosion of a prescriptive nature of doctrine is not new. In 1911 a plea was registered against the 1910 Memorandum on Army Training. Character, it was argued was the implicit factor that mitigated against the construction of a sound doctrinal bridge: "Our General Staff, unlike those of France and Germany, has not taken the opportunity presented to it(assessing the Russo-Japanese War) to impress seriously upon the Army the soundness of that doctrine of war which is the logical and necessary spiritual link between the methods it advocates in Field Service Regulations and the parent conception of war which is the sole justification for adopting any particular method of action". ${ }^{73}$

This debate also underlined how the negative aspect of this component can contribute to doctrinal failure at a tactical level. One of the key functions of training is that it should validate doctrine. This should be the business of a General Staff. They can facilitate dissemination and implementation: "It is among the first duties of the General Staff of a great modern national army to indoctrinate it with a clear conception of the basic principles of war, and of the method on which it intends to apply those principles to the conduct of national war" 74 . What is interesting about national culture as a component of doctrine is that its effects are counter intuitive in terms of the level of war. It is natural to assume that this aspect would impact at the strategic and operational level at the most.

\footnotetext{
${ }^{71}$ D.French,Big Wars and Small Wars between the Wars 1919-1939,Ed H. Strachan Big Wars and Small Wars: The British Army and the Lessons of War in the Twentieth Century, London: Routledge ,2006, p4041.

${ }^{72}$ T.B. Macaulay, quoted in J. W. Burrow, A Liberal Descent, Cambridge: Cambridge University Press 1981 p57.

${ }^{73}$ Ibid p343

${ }^{74}$ Ibidp324.
} 
Yet as the British inter-war example clearly showed its implications manifested themselves at the tactical level.

The final component, the political and strategic situation, infuses a geostrategic ${ }^{75}$ dimension into doctrine. This aspect brings a unique challenge that the armed forces of a particular country have to confront. There is always one constant that remains: human dependence on a geographical base for existence. However, it is the changing conditions that determine how territory will be exploited, contested and defined. It would initially appear that this component would only affect the strategic and operational levels of war.

Germany offers a good example of this. From the inception of a united Germany in 1871 a new strategic situation was brought in to being :"Central Europe was now united for the first time in modern history under the Hohenzollerns, who commanded the finest army in Europe and the world" ${ }^{76}$ Yet military thinkers such as the elder von Moltke had a perceptive grasp of the fact that this new state faced a lethal strategic scenario of a Franco-Russian alliance that could result in a war in two fronts. He also recognized that there was no easy solution, in terms of military planning, to these dilemmas. Yet he was to do his best to find one. The intensive diplomacy of Bismarck with respect to other European powers clearly had its limitations. The problem arose with the accession of Wilhelm II to the throne in 1890, and the desire of a group of General Staff officers around Count von Schlieffen to bring about a rapid decision on the battlefield through manoeuvre and encirclement: "Moltke's plans in this situation were in line with his strategy in the past namely to fight one enemy with as little as possible in order to make available superior forces with which to crush the other. His advice was to stay on the defensive in the west and to take the offensive against Russia. Germany, in possession of Alsace-Lorraine, could defend her western frontier with small forces whereas she could not hope to achieve rapid decisions against the rising line of French fortifications. Greater results could be hoped for in Russia. Moltke's second successor as chief of the general

\footnotetext{
${ }^{75}$ Geostrategy describes the location or locations where a state concentrates its efforts by projecting military power and directing diplomatic effort.

${ }^{76}$ H.H. Herwig, Strategic uncertainties of a nation state: Prussia -Germany 1871-1918.Ed W. Murray, M.

Knox, A. Berstein, The Making of Strategy, Cambridge: Cambridge University Press 1994 p250.
} 
staff, Count Schlieffen, reversed the sequence in 1894; from that time on, the German plans for a two-front war envisaged making the first offensive in the west" ${ }^{, 77}$.

This approach to the political and strategic situation that Germany found itself in did have an effect on the framework that German tactical doctrine developed in .This was discerned by writers before the First World War: "The German method, which in itself is a perfectly logical whole springing from a conception of war in which the ruling factors are held to be seizing and maintaining the initiative at all costs and the envelopment of an enemy whose general direction is often only surmised to avoid loss of time, and consequent loss of initiative, in more accurate verification",78.

In the interwar period under von Seeckt a doctrine was developed that was based on manoeuvre and the rapid annihilation of the enemy force. The other assumption that was made was that the German Army could be rapidly re- equipped and expanded in its numbers. This approach offered a chance of victory instead of the prospect of stalemate. Furthermore, it was not novel but rather a return to the traditions of the past: "Seeckt's conception of modern warfare was not innovative, but rather a return to traditional German warfare. The army had always accentuated the necessity for quick decisive blows. A static defence of Germany has always seemed impossible because of its unfavourable geostrategic position, and its inferiority in material and numbers of men. The enemy armies should not be given a direct target, which they could crush by sheer mass" $" 79$.There was also an element of discontinuity with the past as well. He disagreed with von Schlieffen that fast mobilization was the key to success. ${ }^{80}$ Instead he placed emphasis on using highly mobile forces to make a first strike that would yield decisive results.

By December 1941 Hitler's invasion of Russia, and his declaration of war on the United States, had brought about the two front scenarios that von Moltke had identified. The

\footnotetext{
${ }^{77}$ E.M Earle ,Makers of Modern Strategy, Princeton: Princeton University Press,1943.p185-186.

${ }^{78}$ Edinburgh Review, The British Army and Modern Conceptions of War,Vol113, April 1911, p336.

${ }^{79}$ M. Strohn, Hans von Seeckt and His Vision of a 'Modern Army', War in History Vol 12 no3 2005 p335.

${ }^{80}$ See G.E. Rothenberg, Moltke, Schlieffen , and the Doctrine of Strategic Envelopment, in P. Paret, ed Makers of Modern Strategy from Machiavelli to the Nuclear Age, Princeton: Princeton University Press 1986 ,p306-311(be more specific)
} 
critical difference was the geographical scope of Germany's new enemies. This scope brought about an increase in the material and human resources, plus the technology that was to be deployed and used against Germany. The result was that the considerable tactial and operational virtuosity of the Germany Army was progressively subjected to a dual force: de-modernisation and the loss of the transiting quality in its tactical doctrine.

In conclusion a three fold analysis has been adopted in this article. Doctrine as an object of thought has been evaluated, as well as the two main variants of command philosophy. Secondly, the synthetic nature of the relationship between doctrine and command philosophy has been assessed .It has been hypothesized that they are part of what Fry has described as a compound alignment. This relationship between doctrine and command philosophy is seen as critical by practitioners. Ironically it is completely absent from one of the most recent surveys of doctrine and the British armed forces. ${ }^{81}$ In a perceptive examination of British doctrine in Iraq and Afghanistan there was no reference made to the kind of command philosophy that was being applied to these two operations: "This disquiet was twofold :first there was frustration born of the lack of strategic direction in Iraq and Afghanistan ;second there was a palpable loss of confidence in the robustness of the doctrinal foundations supporting British military operations.. ${ }^{, 82}$ It is the relationship between doctrine and command philosophy that contributes greatly to the ability to generate fighting power. "If doctrine is the epoxy the commander's way of command in the circumstances is the hardener" ${ }^{\prime \prime}$. The importance of aligning doctrine and command philosophy at the tactical level is paramount. However, writers such as Geoffrey Till have generated only confusion as to which command philosophy can generate fighting power when harnessed to doctrine:" There is the balance to be struck between centralized control and that form of delegated authority that has become known as 'mission command' of the sort associated with Nelson.. ${ }^{, 84}$ Moreover a recent insightful article on the challenges that British command philosophy has faced in Iraq and Afghanistan makes

\footnotetext{
${ }^{81}$ See M. Mader, In Pursuit of Excellence,Bern :Peter Lang ,2004.

${ }^{82}$ S. Griffin, Iraq, Afghanistan and the future of British military doctrine: from counterinsurgency to Stabilization ,International affairs, Vol 87,No2,March 2011,p318.

${ }^{83}$ Communication from General Sir Rupert Smith to the author $11^{\text {th }}$ March 2008.

${ }^{84}$ G.Till, Seapower A Guide for the Twenty First Century, London :Frank Cass 2006 p175.
} 
only one attempt to explain the relationship with doctrine: "The independence of these intheatre commanders may be explained by reference to the introduction into the British army of the concept of 'mission command' following Field Marshall Nigel Bagnell's doctrinal reforms in the mid to late 1980s." 85

The third aspect of evaluation has identified the existence of an important lacuna in the theory of doctrine. Gooch argued that the six components of doctrine came together differently in each and every case. They represented a "cocktail" in terms of affecting the formulation, dissemination, and implementation of doctrine ${ }^{86}$. What has been shown is how the different components have manifested themselves at the tactical, operational, and strategic levels of war, and the linkages that exist between these components.

Corbett's aphorism of doctrine being the soul of warfare does underline a crucial continuity from the past to the present and into the future. This continuity can be described as the premier Clausewitzian question ${ }^{87}$. What is the nature of the conflict that statesmen and commanders they find themselves engaged in? It is in the process of answering this question that we have the departure point for the formulation of doctrine and the subsequent command philosophy. The ongoing operation in Afghanistan illustrates this point well.: "The offensive is, in many ways, a distillation of a counterinsurgency doctrine that General McChrystal and his team have been shaping since arriving in Afghanistan last summer" ${ }^{\prime 88}$. The use of doctrine like strategic thinking is heavily context dependent. This is one of the factors that makes doctrine such a transient phenomenon. It is also important underline the point that the utility of doctrine is still contested in the literature. It has been interpreted as being devoid of the ability to generate fighting power and thus facilitate military success : "With each conflict being fought according to quite different political, military and legal requirements from the last,

\footnotetext{
${ }^{85}$ A. King, Military Command in the Last Decade, International Affairs, Vol 87,No 2,March 2011 p390.

${ }^{86}$ J.Gooch, Military Doctrine and Military History, in The Origins of Contemporary Doctrine, The Occasional ,Strategic and Combat Studies Institute No 30 ,September 1997,p6

${ }^{87}$ See p13.

${ }^{88}$ Wall Street Journal ,16 ${ }^{\text {th }}$ February 2010 p1.
} 
the question might be asked: how can doctrine be guaranteed to give us the keys to success on the battlefield? The answer to the question is that it cannot." ${ }^{89}$

The importance of Corbett's wisdom is that it provided, and continues to provide, a pathway to illuminate the continuing importance of senior commanders and policy makers of correctly answering the premier Clausewitzian question. The centrality of this for the formulation of doctrine is ignored by a fighting organization at its peril.

The components of doctrine are not restricted to steering transition from the tactical level to achieving operational effect and strategic objectives. These components at the strategic and operational level can present commanders with difficult challenges at the tactical level. In summary doctrine irrespective of the level at which it manifests itself is pivotal to success in war. This is not exactly a new claim or insight:" There is little or no exaggeration in the assertion that without doctrine large military operations cannot be carried on satisfactorily against a strong and active foe , and that the influence of doctrine upon victory is profound". ${ }^{90}$

Allied to the investigation of the different components of doctrine, the importance of applying the appropriate command philosophy has been emphasized. As stated previously it is this synthesis that generates fighting power. They are like two halves of a banknote each is useless without the other. Of the two command philosophies, the application of 'mission command' is by far the most challenging. It requires certain qualities in an officer corps. Among them is the ability to think holistically, and the willingness to take initiatives and pursue them despite adversity. This in turn underlines the importance of an officer corps to these matters: "If it is indeed true ,as is so often said ,that the officer corps counts for everything in war." $" 1$

A paradigm of doctrine has been developed that would in the future lend itself to being tested by a number of case studies. The use of historical material would illuminate the nature of the thought required to arrive at the conception of war, and establish what kind of doctrines came out of a particular conception. The subsequent doctrines and their

\footnotetext{
${ }^{89}$ O.J. Daddow, Facing the Future: History in the Writing of British Military Doctrine, Defence Studies, Vol 2 ,No 1 Spring 2002 ,p160.

${ }^{90}$ D. Knox ,The Role of Doctrine in Naval Warfare ,United States Naval Institute Proceedings, Vol 41,No 2, ,March -April 1915,p340.

${ }^{91}$ M.Van Creveld, Fighting Power, London; Arms and Armour Press ,1983p168.
} 
accompanying command philosophies could be analyzed for an understanding of the role of both deductive and inductive approaches in this process. It would also illuminate further the critical ability of an armed force to generate fighting power. A knowledge about the relationship between doctrine and command philosophy would enable an evaluation to be made of how effectively the premier question has been posed and answered. 